KAIROS ELT JOURNAL, Vol. 2, No. 3, December 2018

Copyright $\odot 2018$, ISSN: 2580-4278

\title{
IMPROVING STUDENTS' SPEAKING ACHIEVEMENT THROUGH THE APPLICATION OF SMALL GROUP DISCUSSION METHOD TO THE EIGHTH GRADE STUDENTS OF SMP NEGERI 21 MEDAN
}

\author{
Jelita Purba, Linus Rumapea, Novalina Sembiring \\ Catholic University of Saint Thomas
}

\begin{abstract}
This thesis discuss about Improving Students Speaking' Achievement through the Application of Small Group Discussion Method to the Eighth Grade Students of SMP Negeri 21 Medan. The objective of the study was to find out how effective the use of Small Group Discussion Method (SGD) in teaching speaking especially in asking and giving opinion. The study of the research concentrates on the improving students' speaking achievement by the application of small group discussion method. Specifically, it is concerned more about the students' achievement in asking and giving opinion. The research has two cycles. Each cycle has three meetings. The subject of the research was students of Eighth grade students of SMP Negeri 21 Medan which consisted of twenty four students. The instruments of data collection were quantitative and qualitative data. While the quantitative data was conducted by pre-test, posttest I, and post-test II students' speaking score in every cycle, the qualitative data conducted by the three instruments; observation sheet, questionnaire and diary notes. Based on the speaking tests, students' score improved. In the pretest, the mean of the students was 48.82 . The post-test I mean 68.66 and in the post-test II the mean of the students 77.91. Based on the observation sheet, questionnaire sheet and diary notes, it was found that learning activity ran well. Most students felt interested in the process of learning activity and involved in their group during the discussion time. The result of the research showed that Small Group Discussion Method was able to improve students' achievement in asking and giving opinion.
\end{abstract}

Key Words: Speaking, Small Group Discussion, Improving

\section{INTRODUCTION}

Nowadays, most students at Junior High School in Indonesia are familiar with English. Mastering English language as the foreign language is a must for students. In learning English language there are four skills to be taught: listening, speaking, reading and writing. These four skills have their interests. In fact, students' disabilities of those four-skills are still weak especially in speaking. The problematic situation for students in speaking is not able to express what actually they want to say. It is related to Tzu (2007:2) that the teacher usually spends a lot time speaking and explaining curriculum in the class. Students are required to sit in their seats passively and listen to the teacher attentively.

Speaking is one way to communicate which ideas and though a message orally. To enable students to communicate, we need to apply the language in real communication. Speaking is speech or utterances with the purpose of having intention to be recognized by speaker and the receiver processes the statements in order to recognize their intentions. Speaking is quite important to be owned by students in Junior High School. By mastering this skill, they would be able to convey their intention in English and have a confidence to express it when facing native speakers around them.

Based on my observation at the eighth grade students of SMP Negeri 21 Medan class A in the Academic Year of 2016/2017, the students showed many problems in learning speaking. The students showed that the difficulty of learning English coming from their speaking. In addition, I found several problems about students' speaking such as difficulty in vocabulary,

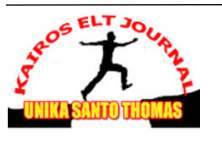


KAIROS ELT JOURNAL, Vol. 2, No. 3, December 2018

Copyright $\odot 2018$, ISSN: 2580-4278

accuracy, pronunciation, fluency. Some factor that cause these problems the teacher's lack of understanding about who the children are, the method used is not suitable for the students. The teacher has taught the lesson well but the method of teaching still makes students hard to speak in English.

Fortunately, learning revolution has been implemented in teaching learning process in the school and it has been socialized to the teachers all over Indonesia. It is also called as Students Centered Learning (SCL ), an approach to education focusing on the needs of the students, rather than those of others involved in the educational process, such as teachers and administrators. Student-centered learning means inverting the traditional teacher centered understanding of the learning process and putting students at the centre of the learning process. It allows students to actively participate in discovery learning process from an autonomous viewpoint. Students spend the entire class time constructing a new understanding of the material being learned in a proactive way. A variety of hands-on activities are administered in order to promote successful learning.

In relation to the problem explained previously, I offer method to be applied in improving students $^{\text {ee }}$ speaking skill by the implementation a Small Group Discussion (SGD) method. Obviously, it must be one of the solutions to solve students ${ }^{\text {ee }}$ problems. Mavis Kelly \& Ken (1993:1) stated: Small group work on the other hand provides opportunities for intellectual and personal growth which cannot be achieved so easily in the standard lecture situation. Because the small group is more personal situation, it provides opportunities for interaction between tutor and lecturer and students and among students.

Hopefully, by the application of Small Group Discussion (SGD) method, students ${ }^{\text {ee }}$ speaking achievement will be improved. Expressions of asking and giving opinion. Expressing opinion is including the words of opinion and argument/reason. In expressing dialogue have two situations, formal and informal. Formal expressions are used in a situation where you are talking in a formal situation, such as in the office or school between the teachers and students. Informal expression used in a situation where you are talking between friends or close friends.

\section{REVIEW OF LITERATURE 2.1 Students' Achievement}

Algarabel \& Desi (2001:44) state that achievement is viewed basically as the competence of a person in an area of content. Cunningham (2012:1) states that the most common indicator of achievement generally refers to a student's performance in an academic area such as reading, language arts, math, science and history as measured by achievement test.

Based on the opinions above it can be concluded that student's achievement is the competence of a student in a specific content, the ability and performance of a student in an academic area. It concerns more on the one's effort of what he/she had learnt.

\subsection{Speaking}

Speaking is depending on the complexity of the information to be communicated; however, the speaker sometimes finds it difficult to clarify what they want to say. In addition, Richards \& Rodgers in Widiati (2006:270) state that speaking is then made the primary aim of language when the direct method come. In the era of this method oral communication became the basis of grading the language teaching programs. According to Artini cited in Widiati \& Cahyono (2006:271) states: Unlike written language, spoken language involves paralinguistic features such as tamber (breathy, creaky), voice quilities, tempo, loudness, facial and bodily gestures, as well as prosodic features such as intonation, pitch, stress, rhythm, and pausing. Thus, spoken language which employs variability and flexibility is in fact as complex as written language, meaning that each is complex in its own way.

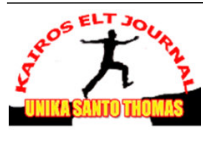


KAIROS ELT JOURNAL, Vol. 2, No. 3, December 2018

Copyright@2018, ISSN: 2580-4278

It can be inferred that Speaking is the activity to report acts, or situation in precise words or to ability to converse or to express a squence of ideas fluently. In fact, it has the same complexity as written language.

\subsection{Asking and Expressing Opinion}

Wardiman A et.al said that expressing opinion is including the words of opinion and argument/reason. In expressing dialogue have two situations, formal and informal. Formal expressions are used in a situation where you are talking in a formal situation, such as in the office or school between the teachers and studentse. Informal expression used in a situation where you are talking between friends or close friends.

Asking for Opinion Formal Situation

- Have you get any comments on...?

- Do you have any idea....?

- Would you give me your opinion on....?

Giving Opinion

- I personally believe....

- I personally consider...

- I hold the opinion....

- If I had my view, I would...

- I think.... - In my opinion

- My own view of the matter of the problem is...

Expressions to Decline an Opinion

-Well, I'm thinking the opposite way....

-I dont think so. To my mind....

-If I may say so,...

-No, thanks
Asking for Opinion Informal Situation

- What do you think of...?

- What are you views ....?

- What are feelings about...?

- Excuse me, Madam. What do you feel about...?

- I'd be grateful to have your views /opinion on...?

Giving Opinion

- I think I like it

- I think it"s good/ nice/terrific...

- In my opinion, I would rather....

- What I have in my mind is....

\subsection{Cooperative Learning (CL)}

Cooperative learning is the instructional practice of placing students into small groups and having them work together toward a common goal. Each group member learns new material and helps other group members learn important information and requires students to work together in small groups to support each other to improve their own learning and that of others. Slavin (1995:2) states that Cooperative learning refers to a variety teaching methods in which students work in small group to help one another learn academic content. Cooperative work rarely replaces teacher instruction, but rather replaces individual seatwork, individual study and individual drill. When properly organized, students in cooperative group work with each other to make certain that everyone in the group has mastered the concepts being taught.

In other word, cooperative learning empowers students in teaching learning process in the classroom because each member of a team is responsible for their team's successful. According to Jolliffe (2007:40) five key elements of cooperative learning are:

1. Positive Interdepedence

Pupils must feel that they need each other and, in order to complete the group's task, that They sink or swim together. They need to feel that they cannot succeed unless everyone does in the group. Some ways to create this feeling are through establishing mutual

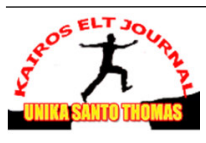


KAIROS ELT JOURNAL, Vol. 2, No. 3, December 2018

Copyright $\odot 2018$, ISSN: 2580-4278

goals(students must learn the material and make certain group members also learn the material); joint rewards (if all group members achieve above a certain percentage on the test, each will receive bonus points); shared materials and information (one paper for each group, or each member receives only part of the information needed to do the assignment).

2. Individual Accountability

Cooperative learning groups are not successful until every member has learned the material or has helped with, and understood, the assignment. It exists when the performance of each individual pupil is assessed and the results are given back to the group and the individual. Thus it is important frequently to stress and assess individual learning so that group members can appropriately support and help each other. Some ways of structuring individual accountability are by giving each group member an individual test with feedback or by randomly selecting one member to give an answer for the entire group.

3. Group Processing

Processing means giving pupils time and procedures to analyse how well their groups are functioning and using the necessary skills. This reflection identifies group strengths and goals. It helps all group members achieve while maintaining effective working relationships among members. Feedback from the teacher and/or student observers on how well they observed the groups working may help processing effectiveness.

4. Small-Group and Interpersonal Skills

Pupils do not come to school with the social skills they need to collaborate effectively with others, so teachers need to teach the appropriate communication, leadership, trust-building, decision-making and conflict-management skills to students and provide the motivation to use these skills in order for groups to function effectively.

5. Face-to-Face Interaction

There are two aspects. The first is the physical proximity needed for effective communication. The second is that it supports thinking skills by more active involvement with the task and greater discussion. Oral summarising, giving and receiving explanations, and elaborating (relating what is being learned to previouslearning) are important types of verbal interchanges.

From the given explanation, we can conclude that cooperative learning has many positive outlooks in teaching learning process in the classroom.

a. Types of Cooperative Learning Groups

According to Jolliffe (2007:43), cooperative learning utilises three types of cooperative learning groups they are:

1. Formal cooperative learning groups:

These last from one lesson to a few weeks and need to consist of the following to work effectively: a) team-building activities to establish team identify and cohesion, b) specific teamwork skills highlighted each lesson and/or week, c) teacher monitoring and support for task and teamwork skills, d) evaluation of learning and teamwork by pupils and teacher.

2. Informal cooperative learning groups:

These last from a few minutes to a whole lesson and usually consist of 'turn to your partner' discussion or think/pair/share and can be extended from pairs to fours or eights (often termed 'snowballing').

3. Cooperative base groups:

This usually last for a term or a school year and consist of heterogeneous cooperative learning groups with stable membership to build on support and encouragement to each other. The elements described in formal cooperative learning groups above will need to be incorporated and built on.

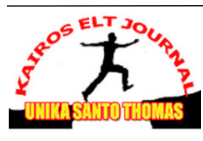


KAIROS ELT JOURNAL, Vol. 2, No. 3, December 2018

Copyright@2018, ISSN: 2580-4278

\subsection{Small Group Discussion Method}

In the previous chapter, it is stated that small groups provide opportunities for interaction among participants. Small Group Discussion is a cooperative learning method which gives more opportunities to students in gathering their ideas, experience, knowledge and actualizing it in speaking. Hence, the teacher should have a good maturity to be able to support his/her students in order to carry out the teaching learning process well. Kelly \& Stafford (1993:4) stated: in order to prepare effectively for a series of $d$ iscussion sessions, teachers need a good appreciation of the level that students have reached, based on their previous experience and the values of the institution in which the work will occur.

In addition, Kelly \& Stafford (1993:4) state that there are a variety of discussion formats, each of which have their own distinctive features and which allow for different degrees of teacher control and student control.

Table 1. Varieties of Discussion Formats

\begin{tabular}{|c|c|c|}
\hline No & Format & Application \\
\hline 1 & Controlled Discussion & $\begin{array}{l}\text { This tecnique is often used to check whether a topic is } \\
\text { understood. It can be used in large group situations as } \\
\text { well as in small groups. Discussion is under the control } \\
\text { of the teacher while students ask questions or make } \\
\text { comments or respond to questions from the teacher. If } \\
\text { practiced at the end of a mini-lecture or video } \\
\text { presentation, for example, the lecturer can obtain } \\
\text { feedback quickly about how well the material has been } \\
\text { understood. It is a limited form of discussion and does } \\
\text { not allow for full participation. }\end{array}$ \\
\hline 2 & Step-by-Step Discussion & $\begin{array}{l}\text { Once again this format is appropriate for large and } \\
\text { small groups. A topic is broken down into several } \\
\text { segments and the lecturer alternates between } \\
\text { presentation of subject matter and discussion periods in } \\
\text { which students can respond to questions of make } \\
\text { comments or ask questions. The focus of discussion } \\
\text { may be notes, a text passage, and videotape and so on. } \\
\text { While it makes use of opportunities for discussion in } \\
\text { large groups, the structure and content of the discussion } \\
\text { make not meet the needs of all group members. }\end{array}$ \\
\hline 3 & Buzz Group & $\begin{array}{l}\text { During the course of a lecture or a discussion led by the } \\
\text { tutor students are asked to turn to their neighbors for a } \\
\text { few minutes to discuss problems in understanding, or to } \\
\text { answer a prepared question, and so on. Buzz groups } \\
\text { enable students to test out their understanding and to } \\
\text { discuss difficulties that they might have been unwilling } \\
\text { to reveal to the whole class. Such groups also provide } \\
\text { the opportunity to stimulate the group by changing the } \\
\text { focus of attention away from the lecturer. However, the } \\
\text { timing is important since, rather than providing a } \\
\text { needed break in proceedings they may cause students to } \\
\text { lose concentration. }\end{array}$ \\
\hline 4 & Snowball Groups & $\begin{array}{l}\text { Buzz group can be extended by progressively doubling } \\
\text { the group size so that pairs join up to form fours, then } \\
\text { fours to form eights. These larger groups finally report }\end{array}$ \\
\hline
\end{tabular}

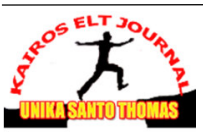




\begin{tabular}{|l|l|l|}
\hline | & $\begin{array}{l}\text { back to the whole group in a plenary session. This } \\
\text { tecnique allows ideas to unfold gradually and allows } \\
\text { students to think for them before bringing their ideas } \\
\text { back to the whole group. However as the group increase } \\
\text { in size the nature of the discussion task may need to be } \\
\text { changed to prevent boredom. }\end{array}$ \\
\hline 5 & Horseshoe Groups & $\begin{array}{l}\text { The class is organized by focusing on the lecturer and } \\
\text { group discussion. Rather than students sitting in rows } \\
\text { facing the front of the room, they sit around tables } \\
\text { arranged in a horseshoe formation with the open end } \\
\text { facing the front. The lecturer can talk from the front for } \\
\text { a time before changing to a group task such as } \\
\text { discussion or problem solving or practical work. In } \\
\text { science and engineering course in particular this } \\
\text { method can be used effectively. Also the teacher can } \\
\text { circulate easily to clear up any problems that may arise. }\end{array}$ \\
\hline
\end{tabular}

Those formats are the varieties of Small Group Discussion Methods (SGD) and the format that is chosen by the researcher to carry out the teaching learning process is Step-bystep Discussion because it is appropriate for large and small groups. Besides, it focuses more on notes, text passage, and videotape and so on.

Finally, we can conclude that Small Group Discussion Method (SGD) is an effective way to be implemented to students because of is benefit in teaching learning process. In otherwords, students not only come to the class and listening to the teacher's passively but also involved in the teaching learning process with the teacher as their guide.

\subsubsection{The Advantages of Small Group Discussion Method (SGD)}

There are many advantages of using Small Group Discussion method (SGD). Rusmussen (1984:4) points out the advantages of Small Group Discussion method are: (a) Small Group Discussion gives learners an opportunity to warm up and try their ideas out in a smaller, less threatening forum than the class as a whole. In turn, this creates an increased likelihood that learners will participate in a plenary session discussion, (b) Small Group Discussion create a diseversity of thought that is likely to enliven the large group discussion which is typically dominated by the comments of the first few participants who set trend and scope of the discussion.

\subsubsection{The Procedure of Small Group Discussion Method SGD Method}

According to Kelly \& Stafford (1993:12) elaborate the procedure of Small Group

Discussion (SGD) method as below:

1. Introductions

There are some way activities that can be used as introduction such us: Individual introduce themselves to the whole groups, people pair off and talk to each other and report back, Small Groups Discuss what they have in common and report back.

2. Ground Rules

Teacher should make clear to the students at the first meeting what is expected of them and what rules will govern future group meetings, for example, what are the rules governing lateness, disruption of the group's activities, methods of participation, as well as rules for speaking in the group is sufficiently mature, it is also a good idea to provide group members with the opportunity to discuss and modify rules for operating before a final "contract" is

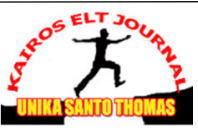


KAIROS ELT JOURNAL, Vol. 2, No. 3, December 2018

Copyright $\bigcirc 2018$, ISSN: 2580-4278

agreed on. Once the ground rules are established, it is up to the teacher or the group as a whole to make sure that they are reinforced.

3. Subsequent meetings

Each subsequent meeting needs a general format which will make the teacher's intention clear to students, reinforce the ground rules, and provide a working structure and link the sessions to previous and future sessions. For example, the following plan might be displayed on a poster, on the whiteboard, or on an overhead transparency are introduce new members or visitors, resolve administrative issues, review previous week's work, students report on progress with a task or report unfinished business, outline the task for today, today's task performed, review progress, project forward to next session, conclude session.

4. Restarting After a Break

Some groups stay together over more than one teaching semester or term and if there has been a break for any reason, you need some procedures for bringing the group together again, no matter how cohesive it was when you last met. You also need to conclude any unfinished business and to signify that the group is moving forward.

5. Encouraging Participation

In many cases students may be reluctant to participate in group discussion because they are not sure of the conventions for speaking, for example, how to take turns, when it is permissible to interrupt, and so on. Furthermore they may think that they do not know enough to make a contribution and fear being assessed negatively on the basis of their spoken contribution.

\section{METHODOLOGY}

\subsection{Research Design}

The research was conducted as an action research and the whole steps in it has cycles which involve a substantive act to hold improvement. Wallace (1998:18) states: The important thing is that process involved are helpful to the practicing teacher's reflection, irrespective of whether they can be verified by someone else. The aim, however, is not to turn the teacher into a researcher, but to help him or her to develop as a teacher, using action research as tool in this process.

Additionally, Wallace (1998:18) states that action research is different from other more conventional or traditional types of research in that it was much focused on individual or small group professional practice and are not so concerned with making general statements. Mettetal (2001:7) states that Classroom Action Research (CAR) is a method of finding out what works best in your own teaching in your own classroom so that you can improve student learning.

From the definition given, it can be concluded that action research is the process which the teacher collaborates in evaluating their practice. It focuses on a specific situation with an integrated solution.

\subsection{The Subject of Research}

The subject of the research is the eighth grade students of SMP Negeri 21 Medan Class A in the Academic Year of 2016/2017. The class consists of 30 students, 10 male students and 20 female students.

\subsection{The Location of Research}

The location of the research was conducted is at SMP Negeri Medan. It is located at Jl. Bunga Rampai, Kec. Medan Johor, Medan. The reason for choosing this school as the location of the research because based on the preliminary study, I want to apply a treatment in order to improve students' speaking skill.

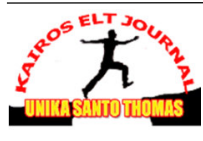


KAIROS ELT JOURNAL, Vol. 2, No. 3, December 2018

Copyright@2018, ISSN: 2580-4278

\subsection{The Instrument of Data Collection}

The data were collected by using quantitative and qualitative data. The Instrument for collecting data was taken from speaking test in doing conversation. It is was given to the students to know their vocabulary, accuracy, pronunciation, and fluency in speaking. Qualitative data are taken from diary notes, observation, questionnaire.

1. Observation Sheet

It is used by observer to observe my performance in doing the classroom action research and the students we indentifying all condition that happen during teaching and learning process. We used an achievement test to measure the students' progress in speaking. The forms of tests are spoken test in the form of conversation. From those forms, we can get score directly the specific learning. The scoring can be done quickly and easily. There are five aspects of assessment in speaking. They are five aspects of assessment in speaking. They are vocabulary, grammar, pronunciation, fluency and comprehension.

2. Questionnaire Sheet

Questionnaire is used to know the students' opinion about small group discussion as the method to improve their speaking achievement that will be applied by us. It is given to the students in the last meeting.

3. Diary Notes

It is recorded everything that happened during teaching and learning process including reflection and evaluation of the teaching and learning process.

\subsection{The Procedure of Research}

Before implementing the research procedure, the researcher administeres the requirements to get the research-license from the school. Afterwards, the researcher identifies the basic knowledge of the students in asking and giving opinion. The procedure of the data collection is conducted in two cycles. Each of the cycle is three meetings. So there are six meetings in the action research included the meeting of orientation test. Each meeting has four phases namely planning, action, observation and reflection.

\section{RESEARCH FINDING AND DISCUSSION}

\subsection{Research Finding}

The finding of this research shown that small group discussion method could improve students' s peaking achievement in conversation. The improvement could be proved from the mean of students's core from pre-test up to post-test II. The mean students's core in pre-test is 48.54 , the mean of the post-test cycle I is 68.04 , and the mean of the post-test cycle II is 76.70 . this improvement did not only happen in the mean of the students's core but also in percentage of the students who passed the KKM. In the pre-test there are 4 students $(16.66 \%)$ from 24 students who passed the KKM, in the postp-test I, there are 14 students $(58.33 \%)$ who passed the KKM, and in the post-test II, there are 20 students $(83,33 \%)$ who the passed the KKM. So, the data indicated that small group discussion was the effectively method because it improved students's peaking achievement in the conversation and helped the teacher to teach speaking skill.

The qualitative data shown taht the students became more eager to receive the conversation material during teaching and learning process. From diary notes, it could be seen that students was very interested and enjoyable in leraning speaking skill and more active in practicing their conversation their conversation by using small group discussion. The questionnaire sheet informed thet most students strongly agree if the English teacher applied small group discussion in teaching speaking. The English teacher also agree that small group discussion method were suitable to be used in the classroom activities ran well. The students had good enthusiastic in learning process. All these data indicated that the application of small

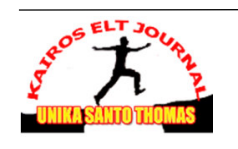


KAIROS ELT JOURNAL, Vol. 2, No. 3, December 2018

Copyright@2018, ISSN: 2580-4278

group discussion had succesfully improved the students' speaking achievement in conversation.

\subsection{Discussion}

Small group discussion were applied to improve students's peaking achievement in coversation at the first grade students of SMP Negeri 21 Medan. when we were doing the reseacrh in SMP Negeri 21 Medan, small group discussion effectively improve students's peaking achievement.

Before we applied the small group discussion as the method in teaching speaking the students were lazy to practice their speaking ability. It shown before we done the reseacrh, we observed the classroom activity when their English teacher taught them and asked them to practice a conversation in the class. They were so lazy to do it and they practice their conversation did not seriously so the result was very bad. Even, when we gave the pre-test, most of them did not respect and did not follow my intructions. That was because they know that we only done the research in their school and they know that it did not affect their English score. So the result of their pre-test was so bad. Only 4 students passed KKM. It was because only them respect and follow my intructions.

In cycle I, when we applied the small group discussion, there were an improvement of the students' participation. Most of all students were more active and interested in practicing their conversation, it was seen from students' post-test cycle I result, some students got high improvement, such as ALX, from 58 to 78 , AY from 47 to 79 , BNG from 44 to 76 , FDH from to 78 , EST from 48 to 80 . It was happened because in pre-test cycle I, they done the test as well as they can. When we explained about the learning material by using small group discussion all of the students have had the good respect, and actively participate when they were asked to do group work and practice their conversation. Even, a students that usually sleep in the class was study seriously with the small group discussion that given by us. Actually most of the students at the class could speak well.

In the next cycle, we had tried to improve her ability in teaching speaking by using small group discussion. In second cycle, all students' score improved, even though there were four students did not passed the KKM. They were AGL, ETR, IML, and KLA. It was occured because the four students so difficult to speak in English. From the explanations above be conclude that small group discussion had successfully improved students's peaking achievement in conversation

\section{CONCLUSION AND SUGGESTION \\ 5.1 Conclusion}

Based on the research analysis, it was cocluded that: Small group discussion method could improve students' achievement in conversation especially for the eighth grade students of SMP Negeri 21 Medan. It was shown by the increasing of students' mean and students' score percentage from pre-test up to post-test II. The students' mean of the pre-test is 48.54 , the posttest I is 68.04 , and the post-test II is 76.70. The students's core percentage who passed the KKM of pre-test is $16.16 \%$, post-test I is $58.33 \%$, and post-test II is $83.33 \%$. From the result, it can concluded that the application of small group discussion method had successfully improved students's peaking achievement.. Small group discussion method can be applied for Junior High School students. It really works if it was applied in a small class consisting of $\leq$ 25 students. The speaking achievement of the eighth grade students of SMP Negeri 21 Medan Academic year of 2016/2017 in conversation improved after they were taught speaking skill by using small group discussion method is a good method to improve students's peaking achievement and increase their participation in classroom activities.

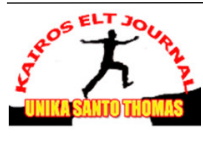


KAIROS ELT JOURNAL, Vol. 2, No. 3, December 2018

Copyright $C 2018$, ISSN: 2580-4278

\subsection{Suggestions}

In line with the conclusion, it is advisable that: Teachers of English should teach speaking skill and conversation lesson by applying small group discussion method it can create a pleasure and exciting learning atmosphere so that the students score active and interested in learning speaking skill. Students of study program teachers training and education faculty, especially who interested in lerning speaking should try appliying small group discussion method in practicing conversation material because it can help you to develop your thinking, increase your vocabulary, and it is very interesting and enjoyable.

\section{BIBLIOGRAPHY}

Algarabel \& Desi. The Definition of Achievement and the Construction of Tests for its Measurements: A Review of the Main Trends. Psicologica. 2001.

Brown, Douglas. Language Assessment: Principles and Classroom Activities. San Francisco State University: Pearson Education Inc. 2007.

Burns, A. Doing action research in english language teaching: a guide for practioners. Sydney: Macquarie University. 2010

Cunningham. Student Achievement. National Conference of State Legislatures. 2012.

Finocchiaro, Brumfit. The Functional-National Approach: from Theory to Practice. New york: Oxford University Press; 1983.

Hewitt, Ralph. Leading Action Research in Schools. United States of America: University of Central Florida. 2005.

Jolliffe. Cooperative Learning in the Classroom Putting it into Practice. Paul Chapman Publishing. London EC1Y 1SP. 2007.

. Cooperative Learning in the Classroom Putting it into Practice. Paul Chapman Publishing. London EC1Y 1SP. 2007.

Kelly \& Stafford. Managing Small Group Discussion.Workshop Series. 1993.

Mettetal, Gwynn. The what, why and how of classroom action research. "Journal of Teaching and Learning.(JoSoTL)”. 2001.

Rusmussen, Ray. Practical Discussion Techniques for Instructors. “AACE Journal”. 1984.

Sanjaya, Dedi. Improving Students Achievement on Writing Descriptive Paragraph Through The Application of Team Pair Solo. Medan: State University of Medan. 2011.

Slavin. Cooperative Learning Theory, Research And Practice. New York: the Hopkins University.

Tzu . The Comparison of the Difficulties between Cooperative Learning and Traditional Teaching Methods in College English. "Journal of Associate Department Applied English”. 2007.

Wallace. Action Research for Language Teachers. United Kingdom: Cambridge University Press. 1998

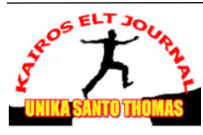


KAIROS ELT JOURNAL, Vol. 2, No. 3, December 2018

Copyright $\odot 2018$, ISSN: 2580-4278

Wardiman A et al. English in Focus 2: for Grade VIII Junior High School: Ed 1. Jakarta: Pusat perbukaan, Departemen Pendidikan Nasional. 2008

Widiati \& Cahyono. The Teaching of EFL Speaking in the Indonesia Context: the of State the Art, bahasa dan seni. 2006 